\title{
Linguistic Analysis of a Literary Discourse for Revelation of Ideology
}

\author{
Lai Peng \\ School of Foreign Languages, Sun Yat-sen University, China
}

Copyright $\bigcirc 2017$ by authors, all rights reserved. Authors agree that this article remains permanently open access under the terms of the Creative Commons Attribution License 4.0 International License

\begin{abstract}
Adopting Van Dijk's theory of ideology as theoretical framework, using Fairclough's dialectical-relational approach as CDA methodology, this paper analyzes the language in a novel written by Mo Yan (莫言), the Nobel Prize winner in literature in 2012, a writer who is adept at describing the Chinese society. In his earlier novel "The Abandoned Baby" (弃贞), he depicted the reality of gender discrimination in Chinese society, aiming to defy traditional ideology and call for gender equality. In order to reveal the dialectical relation between the language he used and the social wrong he tried to address, this paper makes a linguistic analysis of two types of discourse structures in the novel: modality and rhetoric, in terms of their semiotic realization of ideologically based gender discrimination as a social wrong. This linguistic analysis of Mo Yan's literary writing helps to reveal the function of literature which he mentioned after he won the Nobel Prize: to change the society for the better through the use of language. It coincides with the mission of critical discourse studies: to reveal social problems through discourse analysis, thus to raise people's awareness in correcting it.
\end{abstract}

Keywords Ideology, Gender Discrimination, Dialectical-relational Approach, Discourse Analysis, Modality, Rhetoric, Mo Yan, The Abandoned Baby

\section{Introduction}

Chinese writer Mo Yan won the Nobel Prize in 2012 for his hallucinatory-realistic way of writing. Much comments have been given to his Nobel-Prize winning novel "Life and Death are Wearing me Out" in terms of hallucinatory realism, but few analysis has been made about his early writings such as "The Abandoned Baby" [1], which is characterized by sheer realism, without a trace of hallucination, reflecting social reality and traditional ideology. "The Abandoned Baby" is a short novel written in the 1980s, the time when China began to implement the one-child policy for family planning, that is, each couple was allowed to have only one child, so as to control the Chinese population. Under this policy (which had been upheld for more than 3 decades before it was repealed in 2015), in the first few years of implementation, some families chose to abandon female babies in order to have a son. This is due to the traditional ideology deeply rooted in Chinese people's mind: only sons are deemed as heirs of the family, as daughters would have to be married into other people's families. The practice of abandoning female babies was especially common in rural areas of China in those years, as heavy farm work requires that the family have more male members as able-bodied laborers.

Although gender discrimination against female babies is not as intense in urban cities as in rural areas, and abandoning female babies is not prevalent now as it used to be in the 1980s, the traditional ideology of associating male babies with higher value is still present in most Chinese people's mind no matter in urban or rural areas and can still be found in many Chinese couples' longing for a son instead of a daughter. Mo Yan as the writer of "The Abandoned Baby" showed implicit criticism against this kind of traditional ideology and hoped for a change in people's mind.

From the perspective of critical discourse analysis (CDA), discourse (what the speaker/writer said or wrote) may reveal his/her ideology. In terms of literary texts, as is shown above, what the writer wrote may not only unintentionally reveal his own ideology he may also deliberately choose to reveal ideology or problems in the society. To study a literary text such as "The Abandoned Baby", this paper intends to answer the following questions: How did the writer use semiotic strategies to reveal the traditional ideology which caused gender discrimination? What's the dialectical relation between the language used by the writer and the social wrong caused by ideology? CDA theory of ideology and dialectical-relational approach for discourse analysis will be used in combination to analyze the semiotic aspects in "The Abandoned Baby" in terms of the relationship between discourse and ideology. 


\section{Theoretical Framework}

Roger Fowler has always valued ideological analysis for both literary and nonliterary discourses in terms of their underlying belief systems (see [2]). This paper uses Van Dijk's CDA theory in terms of ideology as the theoretical framework for analysis of "The Abandoned Baby". Van Dijk defined ideologies as general systems of basic ideas/beliefs shared by members of a social group [3]. Contrary to the prevailing negative conception of ideology as false consciousness, Van Dijk presented a more general, multidisciplinary theory of ideology which accounts for various kinds of ideologies, both negative and positive ones, including those of resistance. Ideologies, as he pointed out, may be used not only to dominate or oppress others, but also to resist and struggle against such domination, as is known of sexist ideologies and feminist ideologies [3]. In this sense, feminist ideology is an ideology to resist and struggle against gender discrimination and gender inequality caused by sexist ideology.

Elements of the theory of ideology proposed by Van Dijk (2011) are as follows: (1) Ideologies are ideas/beliefs; (2) Ideologies are not individual, personal beliefs, but social beliefs shared by members of social groups; (3) 'Application' of general ideologies in specific situations will make them more useful, e.g., feminists may advocate equal rights and opportunities for women and men, and such a basic norm may be applied to situations in the home, at work, in politics or many other domains of everyday life [3]. He also pointed out that the idea of a shared ideology does not mean that all members of a group will have exactly the same 'copy' of an ideology, and it does not mean that they will apply such an ideology in the same way [3], because ideologies may not be accepted by everyone, and may thus give rise to differences of opinion, to conflicts and struggle [4]. Hence he proposed there is "discourse of resistance" [5].

Van Dijk emphasized the socio-cognitive nature of ideologies as the basis of the shared mental representations of social groups, which in turn will control the social practices of members [3]. As ideology controls social practices (including discourse and other practices), how ideologies may be expressed in discourse and how ideologies influence practices in society are worth studying. One ideologically based social practice in the Chinese society of 1980s was abandoning female babies. This was clearly described by Mo Yan in his writing "The Abandoned Baby". This literary text can be regarded as "discourse of resistance", disclosing sexist ideology and resisting gender discrimination, through the use of language. Van Dijk pointed out quite many ideological discourse structures for analysis [4], among which this paper chose to study modality and rhetoric, in terms of their function in revealing the concept of ideology defined by Van Dijk.

\section{Methodology}

Under the ideological framework by Van Dijk, dialectical-relational approach proposed by Fairclough (2014) will be used as specific steps to follow in terms of the discourse analysis. According to Fairclough, discourse is dialectically related to other elements, being different but not discreet [6]. In his view, CDA focuses not just on discourse, but on the relations between semiotics and other social elements [6]. From this perspective, discourse can be deemed as a kind of semiotic realization of social reality. As Fairclough pointed out, CDA is critical because it aims to address the social wrongs of the day by analyzing their causes and the resistance to these causes [6]. The traditional Chinese ideology described by Mo Yan in "The Abandoned Baby" was the cause of gender discrimination in the Chinese society and the cause of the social wrong of abandoning female babies at the initial implementation stage of one-child policy. That's why the dialectical-relational approach for critical discourse analysis is adopted for this paper, in the hope of addressing the social problem of gender inequality and resisting the traditional ideology which caused it, so as to reveal the relations between discourse and ideology.

The dialectical-relational approach proposed by Fairclough is made up of four stages: Stage 1. Focus upon a social wrong in its semiotic aspect; Stage 2. Identify obstacles to addressing the social wrong; Stage 3. Consider whether the social order 'needs' this social wrong; Stage 4. Identify possible ways past the obstacles [6]. Fairclough pointed out that this approach has been applied in various fields and is unlimited in terms of the fields of application, but certain types of texts like literary texts would seem to pose particular problems [6]. However, this paper is to show that dialectical-relational approach could also be used to analyze literary texts. "The Abandoned Baby" is a good literary example to show the relations between how language is used and how ideology is expressed and to prove that ideological analysis of both literary and nonliterary texts can reveal the underlying values and belief systems embedded in the discourse.

\section{Four-stage Dialectical-Relational Analysis of "The Abandoned Baby"}

\subsection{Stage 1: Identification of a Social Wrong as the Focus of Analysis}

This paper chose to analyze ideologically based gender discrimination as a social wrong. Theory of ideology by Van Dijk (2011) [3] is chosen as the theoretical framework for analysis of the social wrong because he proved discourse structures can be analyzed to show ideology, which is the basis of social practices. This analysis is to look at semiotic realizations of ideologically based gender discrimination in the traditional Chinese society. 
Table 1. Structure of "The Abandoned Baby"

\begin{tabular}{|c|l|}
\hline Part 1 & \multicolumn{1}{|c|}{ I returned from my service in the army and on my way home I saved a baby girl who was abandoned in the sunflower field. } \\
\hline Part 2 & $\begin{array}{l}\text { I took the abandoned baby home and found myself under pressure from my wife who urged me to give this baby away as she believed } \\
\text { she herself could give birth to a second child, preferably a son, as their first child was a girl. }\end{array}$ \\
\hline Part 3 & $\begin{array}{l}\text { I went to the town government for help to deal with this abandoned baby, but I was told by the government official that there were too } \\
\text { many similar problems for the government to deal with, and thus I was required to keep the abandoned baby or to find foster parents } \\
\text { for her. }\end{array}$ \\
\hline Part 4 & $\begin{array}{l}\text { I tried to find somebody to adopt the abandoned baby, but childless families said they only wanted baby boys not baby girls. In the } \\
\text { process of seeking foster parents for the abandoned baby girl, I got an even clearer picture of the social reality: more female babies } \\
\text { being born and being abandoned. }\end{array}$ \\
\hline
\end{tabular}

\subsection{Stage 2: Identification of Obstacles to Solving the Social Wrong}

To identify obstacles to solving the social wrong, we need to find a "point of entry" into it. The "point of entry" [6] involves selecting and analyzing relevant texts. This paper chose a literary text "The Abandoned Baby" as the "point of entry" into the social problem of ideologically based gender discrimination. The analysis of this literary discourse is to show the relation between the semiotic strategies used by the writer and the sexist ideology described by him as the cause of the social wrong. Before making a linguistic analysis of this literary text, the structure of the text needs to be presented to make the social wrong described in it better understood.

"The Abandoned Baby" can be divided into 4 parts according to its chronological sequence. Mo Yan wrote the novel using the first personal pronoun "I", narrating the social wrong he encountered. The content of each part is summarized in Table 1.

At the end of the novel, "I" (Mo Yan as the narrator of the social wrong) hoped for a change in people's mind to get rid of the sexist ideology so that there would be no more gender discrimination against female babies and there would be no more abandoned baby girls. It may clearly be understood from the concluding remarks of this novel that the obstacle to solving the social wrong of abandoning female babies is the traditional sexist ideology of attaching higher value to boys than to girls.

With the general structure of the text made clear, this paper will now focus on the specific linguistic properties of the discourse: modality and rhetoric, to reveal the dialectical relations between these linguistic features and the traditional ideology, which was described by Mo Yan both as the cause of gender discrimination and as the obstacle to solving this social wrong. These two semiotic aspects (modality and rhetoric) are among the many discourse structures pointed out for analysis by Van Dijk (2000) [4] and will be analyzed in this paper as semiotic realizations of ideology (modality as lexical strategy and symbolization as rhetorical strategy). Each of them will be further analyzed in the following sections to show that lexical and rhetoric strategies are vital means to the expression of ideology.
4.2.1. Analysis of Modality (Lexical Strategy and its Relation to Ideology as the Obstacle to Solving the Social Wrong)

The analysis in this part will focus on the use of modal expressions in each part of the novel, in an attempt to reveal its relation to both sexist ideology and power structure, because power structure revealed in this novel also poses difficulty for the narrator to solve the social problem of gender discrimination he witnessed.

Modalities have something to do with the way we represent the world and its events [4]. In this sense, the use of modal expressions conveys something significant in terms of the speaker. As modality is directly related to attitudes and opinions, it is thus a good way to reveal the influence of ideology on the speaker [7]. In ideological analysis, modal structure should be the type of linguistic structure which deserves to be analyzed first (Fowler, 1979, cited from [2]). This is the reason why first and foremost this paper focuses on a modal analysis for the purpose of revealing sexist ideology.

According to Halliday (2000), modality falls into two categories: modalization (degrees of probability or usuality) and modulation (degrees of obligation or inclination). Both types of modality can be expressed by modal operators, modal adjuncts or an expansion of the Predicator [8], i.e., modality can be shown by different forms of modal expressions. Palmer (2001) classified modality and named its subtypes in a slightly different way, but we can find something in common between their concepts of modality. According to Palmer [9], epistemic modality is concerned with the speaker's attitude to the truth-value or factual status of the proposition (=modalization, showing degrees of probability), deontic modality relates to obligation or permission emanating from an external source (=modulation, showing degrees of obligation), while dynamic modality relates to ability or willingness emanating from the internal source (=modulation, showing degrees of inclination). This paper will make use of both Halliday's and Palmer's technical terms of modality in the analysis of modal sentences from "The Abandoned Baby". 
Modal sentences for analysis are extracted mainly from dialogues in each part of this Chinese novel (because in dialogues the speakers' use of modal expressions can convey their attitudes and ideology) and are presented below, followed by its English version (translated by the author of this paper). Then a detailed analysis will be made concerning the relationship between semiotic use of modality and revelation of ideology.

\subsubsection{Analysis of Modality to Show Ideology as a Shared Belief}

Analysis in this part is based on modal sentences (1)-(2) which are extracted from Part 2 ( "my" family members reacted negatively at seeing the abandoned baby): (1) 妻子 愤怒地说: “我能生! ”(2) 母亲说: “先养着吧, 先养着, 打听打听看有没有缺孩子的。你们行了这个善, 下一胎 一定能生个男孩。”(1) My wife said indignantly: “I (myself) can bear a son!" (2) My mother said: "Keep the baby for a while before you find a childless family to adopt her. Doing this good deed, you will surely be able to give birth to a son next."

The use of modal expressions by the main characters in the novel is closely related to traditional Chinese ideology concerning gender. In each of the above two sentences, the Chinese modal operator "能” (=can/could or be able to, showing ability) was used. In sentence (1), the wife expressed indignation at seeing a baby brought back, thinking that it must be a baby boy adopted by her husband because she was thought to be unable to bear a son. Her use of modal operator “能” (can) in "I (myself) can bear a son!" (dynamic modality, showing ability) is a protest which shows her belief in her own ability to bear sons and reveals her ideology of longing for the birth of male babies. At that time in China, if a woman gave birth to only daughters and seemed unable to bear sons, she would feel pressure from the society due to discrimination against her inability.

In sentence (2), the mother said: "Doing this good deed, you will surely be able to give birth to a son next." The Chinese modal adjunct “一定” (=surely, showing high degree of probability) together with the Chinese modal operator "能” (=be able to, showing ability) shows the belief behind what she said: People will have a son in return for the good deeds they have done. The use of epistemic modality and dynamic modality together in this sentence shows Chinese people's strong superstitious belief that the good deeds they do will enable them to have sons in return. For those who are longing for the birth of sons, they try to do good deeds or a variety of other things in order to fulfill their wish for a son. This kind of longing for sons conveys the idea that Chinese people believe boys have higher value than girls. It is a kind of long-ingrained belief in Chinese society, and still remains to be overcome.

From sentence (1) and (2), we may understand that traditional ideology of attaching importance to the ability of bearing sons is a belief that boys have higher value than girls, a basic idea shared by people in the Chinese society (in this novel, "my" wife and "my" mother, and those who abandoned female babies). The ability of bearing sons is extremely important for women in Chinese society at that time and they would do everything to achieve this ability in return. The above modal expressions they used in their dialogues clearly revealed their ideology, as modality shows attitudes and opinions, which are ideologically based.

\subsubsection{Analysis of Modality to Show Unequal Power Relationship}

Analysis in this part is based on modal sentences (3)-(5) which are extracted from Part 3 ("I" tried to ask for help from the government official to deal with the abandoned baby): (3) “领导, 你就这种态度? 又不是我的孩子, 凭什么要我养 着?”政府人员说: “你不养着难道要我养着? 乡政府又 不是托儿所。”(4) 我说: “不行, 我不能养。”(5) 他说: “你去打听打听, 看有没有孤寡要抱养孩子的, 没有, 你 就只好养着她。你的家属在农村? 有了一个孩子? 你养 着她, 想落户口就算你生了二胎, 罚款两千元! ”(3) "Leader, how can you make this request? She is not my baby, why must I bring her up?" The government official said: "Must I bring her up then? The town government is not a nursery." (4) I said: "No, I can't bring her up." (5) He said: "You try to find a childless family to adopt her. If nobody wants to adopt her, you have to keep her. Your wife is in the countryside, isn't she? You've got a child already, right? If you keep this abandoned baby and want to register her as a member of your household, then she is counted as your second child, (according to the one-child policy) you will have to pay a fine of 2000 RMB! (Note: this is a huge sum of money at that time)"

In two of the above three sentences, the Chinese modal operator “要” was used. “要” is a high value modal operator which has double meanings. It can express both deontic modality (=must or have to, showing high degree of obligation) and dynamic modality (=want to or be determined to, showing high degree of willingness) [10]. Sentence (3) is a dialogue, in which the use of “要” (=must, showing a request) reveals clear power relationship between the government official and "me". The force of obligation for "me" to bring up the abandoned baby comes from the government official as an external source. The use of high value deontic modal operator “要” (must) as a request shows the authoritative power and overbearing status of the government official, presenting a picture of power inequality between him and "me". By analyzing the modal expressions we can see that "discourse plays a pivotal role in the exercise of power" [5].

In sentence (4), modal operator “能” (can) in its negative form “不能” (= can't) shows not only low degree of willingness but also inability, because "I" was unwilling to keep the baby and unable to bring her up, due to economic reasons. But as a result of the unequal power relationship, "I" had no other choice, as shown in sentence (5), in which the government official used Chinese modal adjunct “只好” (= have to) to show high obligation for "me" to keep the baby if 
nobody else wants to adopt her (wants to =“要”, showing degree of willingness, which belongs to dynamic modality in this sentence). The government official's request conveys authoritative power which "I" was not in a position to disobey. Being unwilling to keep the baby but forbidden to throw her away, "I" was put in a dilemma, unable to defy either the traditional sexist ideology (which caused both the practice of abandoning female babies and the fact that nobody wanted to adopt female babies) or the unequal power relationships (between the official as the dominating one and "me" as the dominated one). Through Mo Yan's use of modal expressions in these dialogues we can see the relation between lexical strategy and social elements (such as gender inequality and power inequality), and we can clearly understand the obstacle to solving the problem of the abandoned baby. It was ideologically based gender discrimination under the circumstance of one-child policy in China at that time that led to the practice of abandoning baby girls. But the government official's job was only to implement the one-child policy and make people pay a fine for having a second child. He did not take it as his job to solve the problem of abandoned babies or to change the sexist ideology in people's mind. "I" was required to keep the abandoned baby or find foster parents for her.

\subsubsection{Analysis of Modality to Show Ideology as the Basis of Social Practice}

Analysis in this part is based on modal sentences (6)-(8) which are extracted from Part 4 ("I" tried to find foster parents for the abandoned baby): (6) 我走遍了全乡十几个 村庄, 拜访了所有缺儿少女的家庭, 得到的回答几乎都 是一样的: 我们不要女孩, 我们要男孩。(7) 如果在医院 妇产科工作的姑姑也不能帮我把这个女贞推销出去, 十 有八九我就成了这个女婴的养父了。(8) 姑姑说: “是黑 水口子的老婆, 生了三胎了, 三个女孩, 这一胎憋足了 劲要生个儿子, 生出来一看, 还是个闺女。她男人一听 说又生了个闺女, 赶着马车就跑了。世界上难找这样的 爹。女人一看丈夫跑了, 从产床上跑下来, 提上裤子, 哭着跑了。连孩子都不要了。”(6) I visited all the villages in this region and asked all the childless people in the area, who unanimously gave me the same answer: We don't want baby girls, we want baby boys. (7) If my aunt who works in a hospital as an obstetrician is unable to recommend a childless family for adoption of the abandoned baby, I myself will probably become her foster parent. (8) My aunt said: "This baby was abandoned by Heishui's wife. She has given birth to three girls already, and was determined to have a boy. But this fourth one turned out to be a girl again. Her husband ran away at hearing this. How could there be such a heartless father? Seeing that her husband had run away, she got off the obstetric bed and ran away too, abandoning the baby."

Modal operator “要” in sentence (6) and sentence (8) both express dynamic modality (= want to or be determined to) to show people's high inclination to have a boy, but no inclination to have a girl, which reveals the traditional ideology of attaching higher value to boys than to girls. From sentence (8) we can see that some couples were so determined to have a baby boy that new-born baby girls might even be abandoned right in the hospital where they were born. As ideology is the basis of social practice, in this case, it is sexist ideology that leads to the common practice of abandoning female babies. In this sentence, the use of "be determined to" (an expanded Predicator to show high degree of inclination to have boys instead of girls) reveals great influence from traditional sexist ideology.

Chinese modal adjunct “十有八九”(=probably) in sentence (7) was used to show high degree of probability that "I" might have to become the foster parent of the abandoned baby girl if even the obstetrician is unable to (=“不能”) recommend any childless people who would like to adopt her. These modal expressions in the sentence reveal the social reality of prevalent gender discrimination against female babies. As is pointed out by Van Dijk, sexist ideology is at the basis of gender discrimination [4].

Modal expressions in sentences (6)-(8) showed that traditional sexist ideology which caused gender discrimination is not individual, personal beliefs, but social beliefs shared by members of the Chinese society, as sentence (6) showed, all the childless families said they wanted only baby boys. Ideologies are forms of shared social cognition at the level of groups, they are shared mental representations that are used or applied as a basis for the specific ideological conduct of group members [3]. Hence it is clear that traditional sexist ideology in China in the 1980s was the basis for the conduct of abandoning female babies or refusing to adopt female babies, which was common among the members in the Chinese society at that time. The obstacle to solving this problem is thus made even clearer: the traditional ideology, which is the basis for social practices.

Writers or speakers will use various modal expressions in the discourse to convey certain ideology to the readers or listeners [2]. The above analysis presented how sexist ideology against female babies was revealed by Mo Yan through the way he used modal expressions. With the dialectical-relational approach to analyze his use of language, it could be shown how ideology is encoded in the linguistic representation of the social reality, thus the ideology theory proposed by Van Dijk could be understood better. Analysis of the above modal sentences (1)-(8) made it clear how the discourse reveals ideological meaning through lexical strategy such as the use of modal expressions. Discourse (as semiotics) and ideology (as social elements) are dialectically related to each other in this sense. As Mo Yan narrated how he struggled for solution of the abandoned baby, his semiotic way of revealing sexist ideology made it explicit that the traditional ideology long-ingrained in the mind of Chinese people is the obstacle to solving the social wrong of abandoning female babies. 
4.2.2. Analysis of Symbolization (Rhetoric Strategy and its Relation to Ideology as the Obstacle to Solving the Problem)

Semiotic strategies include rhetoric ones as well as lexical ones. Rhetoric strategies are figures of style which have implied meaning. To know what ideological implications such figures of style have, we need to examine the meanings they organize [4]. In literary writing, "symbolization" as a figure of style plays an important role in embodying the theme. It's a kind of semantic device for the enhancement of implied meaning. In "The Abandoned Baby", sunflower field where the abandoned baby was picked up was described again and again throughout the novel. It must have carried some implied symbolic meaning. What's the implication of the sunflower field in relation to the theme of resisting sexist ideology? To understand this, we are going to examine all the sentences describing sunflower field and analyze their symbolic meaning.

Sentences (9)-(11) are extracted from Part 1, before the abandoned baby was discovered. (9)那片葵花地顿时就变 得非常遥远, 像一块漂游在大地上的云朵, 黄色的、温 柔的、馨香扑鼻的诱惑强烈地召唤着我。(10) 葵花, 黄 色的葵花地, 是葛利高里和阿克西妮亚幽会的地方, 是 一片引人发痴的风流温暖的乐园。(11) 稀疏种着的葵花, 它们高大、孤独, 给人以欺凌者的感觉。成片的葵花温 柔、亲密、互相扶持着, 像一个爱情荡漾的温暖的海洋。

(9) The sunflower field suddenly seemed far away, like a distant cloud floating over the land, waving at me with yellow, tender and scented temptation. (10) The field, filled with yellow sunflowers, was a place where Gregory and Akcenia dated each other, a paradise thronged with craziness, tenderness and sweetness. (11) Sparsely planted sunflowers along the road looked stately and aloof, like overbearing bullies, while tightly packed sunflowers in a field seemed gentle, intimate, and supportive of each other, like a warm sea seethed with love.

The above three sentences described the image of the sunflower field in the narrator's eyes before he knew a baby girl was abandoned there. Sunflowers at that time had a positive image in his mind: yellow, warm, tender, and supportive of each other, sharing the sunshine and enjoying the sunny days. The sunflower field was thus perceived by him as a place of love, a paradise. Readers may not realize that the sunflower field has symbolic significance until they have read the description of it after the narrator saved the abandoned baby from the sunflower field, which was described as follows.

Sentences (12) and (13) are extracted from Part 1 and 2, when the baby was picked up and after she was brought back to the narrator's home. (12) 碗大的无数花盘挑在柔软的 弯颈上, 像无数颗谦恭的头枆。我循声钻进葵花地, 金 子般的花粉雨点般落下, 落在我的头发和手臂上, 落进 我的眼睛里....... (13) 我蹲在盛女贞的竹篎子旁边时, 经 常想到那片黄光灿烂的葵花地, 那些碗口大的头颅沉重 地低垂着, 机械地、笨拙地围着自己的茎杆转动, 黄色 的花粉泪珠般落在地上, 连蚂蚁的巢穴都淹没了...... (12)
Numerous sunflowers drooped on their stalks, like countless humble heads. Following the sound of the crying baby, I got into the sunflower field. Golden pollens fell like rain drops, landing on my hair and arms, and sprinkling into my eyes... (13) As I squatted beside the bamboo cradle in which the abandoned baby was sleeping, I often thought of the yellow sunflower field, in which those drooping flowers clumsily revolved around their own stalks, with yellow pollens falling on the ground like tears, flooding the ants' dens...

In sentences (12) and (13), sunflowers were described as countless humble heads, drooping as if in sadness, because a baby was found abandoned in the sunflower field. Pollens falling from the sunflowers were perceived as rain drops or even tears, because the abandoned female baby made the narrator aware of the sexist ideology, which made him sad and moody. The change from positive perception of the sunflower field to negative perception of it helps to construct a gloomy atmosphere of the social reality -- female babies being abandoned due to the influence of traditional sexist ideology. The symbolic meaning of the sunflower field begins to zoom in, but it may not become clear enough until readers go on to the following part of the story, where they will read the following sentences.

Sentences (14) and (15) are respectively extracted from Part 3 and 4, when the narrator encountered frustration again and again while seeking help to deal with the abandoned baby. (14) 一切都说明, 这是一个漂亮的、健康的女婴。 面对着这样热诚的、像葵花一样辉煌的生命 --- 我又一 次想到金黄的葵花地。(15) 我坐在葵花地里发愣。没有 阳光, 因为空中密布着破絮般的灰云。葵花六神无主, 悲哀地、杂乱地垂着头。...... 然而, 葵花地里毕竟充满 希望。无数低垂的花盘, 像无数婴孩的脸盘一样, 亲切 地注视着我。(14) Everything suggested that it was a healthy pretty baby girl. Faced with her vibrant life which was as splendid as the sunflower, I again saw the yellow sunflower field in my mind's eye. (15) I was lost in a trance while sitting in the sunflower field. There was no sunshine, as the sky was densely covered with dark clouds, floating here and there like cotton balls. The sunflowers were in a state of stupefaction, with their heads drooping in sadness. ... Nonetheless, the sunflower field was filled with hope. Numerous sunflowers, just like lovely faces of countless babies, looked at me in earnestness and friendliness.

In sentence (14), the pretty and healthy abandoned baby was compared to splendid sunflowers. We may now understand that the symbolic meaning of sunflower is vibrant life, healthy being. The female baby was abandoned not because of health problems or ugly appearance, but because of her gender. In sentence (15) it is clear that without sunshine the sunflowers may lower their heads as if in sadness. This makes me realize that the sunshine symbolizes gender equality. With the sunshine, each sunflower (each life, no matter male or female) will be enjoying the warmth and brightness equally, growing happily and healthily. Without the sunshine, sunflowers will drop into sadness and gloominess, with their pollens falling like tear drops. In this 
case, the sunflower field in sunshine symbolizes a land of warmth, love and gender equality, while the sunflower field without sunshine symbolizes a land filled with sexist ideology and gender discrimination. The sunflower field without sunshine is a metaphor for the existing social reality at the time when the narrator told the story, when most Chinese people were influenced by the traditional sexist ideology. But the sunflower field in sunshine is a symbol for expected future society in the eyes of the narrator, who tried to resist sexist ideology and call for sunshine/brightness/equality. That's why the sunflower field can be perceived both positively and negatively, depending on whether there is sunshine, which stands for the liberating ideology of gender equality, i.e., the feminist ideology. The symbolic description of the sunflower field and the sunshine thus clearly has their relations to the theme of resisting sexist ideology.

Through the rhetoric strategy of symbolization, we not only understand the traditional sexist ideology as an obstacle that the narrator tried to overcome, we also get an idea of the narrator's own ideology, feminist ideology. The narrator actually constructed a "discourse of resistance" by rhetorically describing the existing social reality (symbolized by the sunflower field without sunshine) and presenting in contrast the image of the expected future society (implied by the sunflower field in sunshine). In this paper, symbolization is shown to be closely related to other social elements, e.g., the ideology in the society. Mo Yan as the story narrator and the discourse constructor used rhetoric strategy as semiotic realizations of social reality.

\subsection{Stage 3: Evaluation of the Social Wrong}

Following the steps for analysis according to the dialectical-relational approach, we get to understand better the narrator's use of lexical and rhetoric strategy in the discourse and its relation to ideology. Through this literary text, the writer revealed not only traditional sexist ideology which caused the social wrong of abandoning baby girls he also revealed his own feminist ideology of longing for gender equality. He showed his struggle and resistance against the social wrong by describing his efforts in solving the problem and his frustrations when encountering obstacles. We thus understand that the social wrong of abandoning female babies is a problem to be solved, a negative practice to be eradicated. It's not needed in the future society.

\subsection{Stage 4: Identification of Solution to the Social Wrong}

From the analysis of modal expressions and rhetoric symbolization in "The Abandoned Baby", readers may understand that the solution to the social wrong of abandoning female babies is to change the traditional sexist ideology which is ingrained in Chinese people's mind. This is also made clear by the writer in the ending paragraph of this novel:

(16) 在这片盛开着黄花的土地上, 问题多复杂。医生 和乡政府配合, 可以把育龄男女抓到手术床上强行结扎, 但谁有妙方, 能结扎掉深深植根于故乡人大脑中的十头 老牛也拉不转的思想呢? (16) But things are a lot more complicated on this land which is dotted with blooming sunflowers. With the coordination of doctors and government officials, couples at child-bearing age could be forced to go through the ligation operation to be physically prevented from giving birth to more than one child, but who has a wonder drug to eradicate the traditional sexist ideology in the mind of my countrymen? It's so deep-rooted that even the strength of ten oxen together wouldn't be able to pull it up by the roots.

The above sentence clearly states that traditional sexist ideology is the obstacle to solving the problem of abandoning female babies in China (land dotted with sunflowers is a symbol of Chinese countryside). At the end of the novel Mo Yan pointed out that the practice of abandoning babies could be found in other countries too, but it was not necessarily caused by ideologically based gender discrimination as it was in China. Ideologies are defined in terms of mental models for groups, and ideologically 'biased' mental models control all our ideological practices [3]. The solution to the practice of abandoning female babies is to change Chinese people's mental model, which is both the cause of gender discrimination and the obstacle to gender equality. But as is shown in sentence (16), it is very hard to achieve that, because ideologies as mental models are too deep-rooted to be eradicated. Possible ways to solve the problem is for people to gradually unlearn this kind of sexist ideology. This is why Mo Yan wrote this novel, which can be deemed as an anti-sexist discourse, disclosing the social wrong of abandoning female babies, resisting the oppressive sexist ideology, in the hope to wake up people's sense of gender equality. This novel is actually Mo Yan's application of ideology to literature for readers to unlearn sexist ideology and acquire feminist ideology, with the purpose to change the society for the better. As Van Dijk pointed out, application of ideology in specific situations may make it more useful [3]. By applying ideology to literature, Mo Yan tried to make use of the influence of literature to arouse people's resistance to sexist ideology and to raise public's awareness of gender equality.

\section{Concluding Remarks}

Ideology and discourse are not the same. However, they are related, not discreet from each other [6]. That's why dialectical-relational approach is adopted for discourse analysis in this paper to show relations between semiotic strategies used by Mo Yan and ideology theory defined by Van Dijk. Sexist ideology caused gender inequality. Inequality of different kinds exists in our society and is 
reflected in the discourse. Discourse as semiotic realization of social reality could thus be studied and analyzed to show its relation to ideology, which is described as the obstacle to solving the social wrong. The language in "The Abandoned $B a b y "$ is analyzed in this paper to show how ideology is revealed through language, how social practices are influenced by ideology, and how gender inequality is described as a social wrong. Mo Yan, the writer of "The Abandoned Baby", while criticizing sexist ideology and calling for gender equality, showed his own underlying values, i.e., feminist ideology. It's an ideology of resistance, "a liberating ideology" [3]. By writing this novel, Mo Yan called for ideological change toward gender equality in the future society. In his eyes, to change the society for the better is one of the functions of literature. This coincides with the goal of critical discourse studies (CDS), which is to "oppose power abuse and domination (in the society), such as racism, sexism, and so on" [3]. According to Talbot, who is a feminist who adopted CDA for gender research, critical discourse analysis could be an impetus to promote liberation and equality [11]. Mo Yan resorted to the use of language to liberate people from the oppressive sexist ideology. A dialectical-relational analysis of the lexical strategy and rhetoric strategy in his novel "The Abandoned Baby" helps not only to show the relationship between semiotics and ideologies but also to identify ideology as the obstacle to solving the social wrong. As "The Abandoned Baby" has seldom been studied and has never been analyzed before from the perspective of CDA, this paper is a worthy try to use sentences from this literary text as data for discourse analysis, in the hope to show the function of both literary writing and discourse studies, that is, to reveal the ideology and to better the society.

\section{REFERENCES}

[1] Mo, Y. The Abandoned Baby. Available at: http://www.360doc.com/content/12/1014/23/233880_241508 323.shtml; 1986.

[2] Li, J. The Expression of Modality and the Revelation of Ideology. In: Huang G W et al. (eds) Functional Linguistics: Theory and Application. Beijing, China: Higher Education Press; 2005: 173-182.

[3] Van Dijk, T. A. Discourse and Ideology. In: Van Dijk T A (ed.) Discourse Studies. A Multidisplinary Introduction $\left(2^{\text {nd }}\right.$ edition). London: Sage; 2011: 379-407.

[4] Van Dijk, T. A. Ideology and Discourse: a Multidisciplinary Introduction. Available at:

www.discourses.org/download/books; 2000.

[5] Van Dijk, T. A. Critical Discourse Studies: A Sociocognitive Approach. In: Wodak R \& Meyer M (eds) Methods of critical discourse analysis ( $3^{\text {rd }}$ edition). London: Sage; 2015: 63-85.

[6] Fairclough, N. A Dialectical-relational Approach to Critical Discourse Analysis in Social Research. In: Wodak R \& Meyer M (eds) Methods of Critical Discourse Analysis, ( $2^{\text {nd }}$ edition). Beijing, China: Peking University Press; 2014: 162-186.

[7] Chen, Z.Z. A Review of Critical Linguistics. Foreign Language Teaching and Research, 1995 (1): 21-27.

[8] Halliday, M. An Introduction to Functional Grammar (2 $2^{\text {nd }}$ edition). Beijing, China: Foreign Language Teaching and Research Press; 2000: 89.

[9] Palmer, F. Mood and Modality ( $2^{\text {nd }}$ edition). Cambridge: Cambridge University Press; 2001: 10.

[10] Lai, P. A Study on the Causes of Interlingual Transfer Errors in the Acquisition of Chinese Modal Auxiliaries. Language Teaching and Research, 2006 (5): 67-74.

[11] Talbot, M. Language and Gender: An Introduction. Wuchang, China: Huazhong Normal University; 2004: 306. 